\title{
DETERMINATION OF SUITABLE GROUNDWATER QUALITY FOR AGRICULTURE BY USING GIS APPLICATION IN BANTUL REGENCY, YOGYAKARTA SPECIAL PROVINCE, INDONESIA
}

\author{
Chhuon Kong*1, Heru Hendrayana ${ }^{2}$, and Agung Setianto ${ }^{2}$ \\ ${ }^{1}$ Institute of Technology of Cambodia, B.P. 86, Blv. Pochentong, Phnom Pehn, Cambodia \\ ${ }^{2}$ Department of Geological Engineering, Faculty of Engineering, Universitas Gadjah Mada
}

\begin{abstract}
In order to evaluate groundwater quality for irrigation purposes within Bantul area which is located on Yogyakarta Volcanic Groundwater Basin, 47 existing data points were used complementary with the results of 30 groundwater samples analysis which were collected from dug and tub wells in various locations of study area. ECw, TDS, $\mathrm{pH}$ and major cations: $\mathrm{Na}^{+}, \mathrm{Ca}^{2+}, \mathrm{Mg}^{2+}, \mathrm{K}^{+}$, and anions: $\mathrm{Cl}^{-}$, $\mathrm{HCO}_{3}^{-}, \mathrm{SO}_{4}^{2-}, \mathrm{NO}_{3}^{-}$were analyzed as evaluation index. The relative tendency of ion in epm shows $\mathrm{Ca} 2+>\mathrm{K}+>\mathrm{Na}+>\mathrm{Mg} 2+$ and $\mathrm{HCO}_{3}^{-}>\mathrm{Cl}^{-}>\mathrm{SO}_{4}^{2-}$. Variations in groundwater composition by using $\mathrm{Mg} / \mathrm{Ca}$ vs. $\mathrm{Na} / \mathrm{Ca}$ molar ratio indicates that the groundwater is close to silicate rock with influence of clastic carbonate rock. Higher salinity approach to the west of the Bantul indicates that groundwater quality is controlled by clastic carbonate rock and expose limestone of Sentolo hills. Groundwater samples fall under class I suggested that groundwater is good and suitable for irrigation based on Doneen's classification of permeability index and $78.37 \%$ is in excellent category by Wilcox classification on N\%. According to the SAR values plotted in the USSL diagram, the majority of the groundwater samples belong to C2-S1 and C2-S2 class, indicating medium salinity and low sodium water which

${ }^{*}$ Corresponding author: C. KONG, Institute of Technology of Cambodia, B.P. 86, Blv. Pochentong, Phnom Pehn, Cambodia. E-mail: chhuon.k@gmail.com
\end{abstract}

can be used for irrigation with little danger. The suitability of groundwater quality for agriculture is determined by thematic maps produced from Arc GIS Spatial Analyst based on FAO guideline. Salinity is the significant problem that has slight to moderate restriction effect on crops productivities in this area. The ECw map indicates that good groundwater quality for crops is at the middle to the east of study area close to Opak River, while at the western irrigation water is affected but yielding no reduction on rice productivity. However, it has slight to moderate restriction on sensitive crops indicated in thematic map of crops land with different yield potential. The agricultural land in which has yield potential of $100 \%, 90 \%$ and $75 \%$ is about $2727.90 \mathrm{ha}(38.56 \%)$, $735.49 \mathrm{ha}(10.39 \%)$ and $208.98 \mathrm{ha}(2.95 \%)$ of the study area respectively.

Key words: Irrigation groundwater quality, total dissolved solids (TDS), electrical conductivity (EC), evaluation index, ArcGIS Spatial Analyst, FAO guideline, yield potential.

\section{Introduction}

Groundwater plays a major role in augmenting water supply to meet the ever-increasing domestic, agriculture, and industrial demands. The chemical composition of water is an important factor to be considered before it is used for domestic or irrigation purpose. Characteristics of water quality through physical, chem- 
ical and biological definition influence the crop production. Salts in soil or water reduce water availability to the crop to such an extent that yield is affected (Bernstein, 1975). Relatively high sodium or low calcium content of soil or water reduces the rate at which irrigation water enters soil. Certain ions (sodium, chloride, or boron) from soil or water accumulate in a sensitive crop to concentrations high enough to cause crop damage and reduce yields. Excessive nutrients reduce yield or quality; unsightly deposits on fruit or foliage reduce marketability.

Availability of adequately good quality water is one of the most important inputs in successful crop production. Anthropogenic activities also influence the role of evaporation that lead to an increase in $\mathrm{Na}^{+}$and $\mathrm{Cl}^{-}$and thus total dissolved solids (TDS). It is therefore obvious that the groundwater contribution is a significant component of water balance and should be recognized as providing part of the water needed by the crop for evapotranspiration. Accordingly, this study is armed to evaluate and determine the suitability of groundwater quality for crop influenced by irrigation water and to define the water constituents which may restrict crop yield in the study area.

Geographic Information System (GIS) application is very necessary to be used integratedly with hydrogeology and agriculture in facilitating various technical works. GIS is also a potential tool for facilitating the generation and use of thematic information that has been applied for identification of suitable groundwater quality zone for domestic and irrigation purposes. It is one of the best and fastest systems for this objective (Ganapathy and Ernest, 2004).

The study area is located in the Java Island and administratively covered the share of 5 districts or approximately $70.743 \mathrm{~km}^{2}$ within Bantul Regency, Yogyakarta Special Province (DIY), Indonesia (Figure 1). Topographically, the study area is located on the Lower Slope Merapi Volcanic Zone, an almost flat area. Its lithology is mostly resulted from volcano activity; other part is Tertiary clastic sediment. It consists of limestone, young volcanic deposits, and alluvial and old andesite volcanic deposits (MacDonal and Partners, 1984b).
Table 1: Landuse distribution in the study area.

\begin{tabular}{|l|c|c|}
\hline \multicolumn{1}{|c|}{ Categories } & Area $(h a)$ & $\begin{array}{c}\text { Percentage } \\
(\%)\end{array}$ \\
\hline 1. Rice field & 3297.977 & 46.62 \\
\hline $\begin{array}{l}\text { 2. Other } \\
\text { cultivated land }\end{array}$ & 381.403 & 5.391 \\
\hline 3. Field soil & 51.511 & 0.728 \\
\hline 4. Settlement & 3274.851 & 46.292 \\
\hline 5. Shrub & 28.799 & 0.407 \\
\hline 6. Water body & 38.782 & 0.548 \\
\hline Total & $\approx 7074.3$ & $\approx 100.00$ \\
\hline
\end{tabular}

Land use is widely distributed in fluvial volcanic plains. In general, land use in the study area is categorized as in Table 1 .

\section{Material and methods}

In order to evaluate and determine the suitable quality of groundwater for crops influenced by irrigation, water quality data is indispensably needed. Analysis of the groundwater composition and its interaction with rock used Schoeller diagram in order to determine the relative tendency of dissolved ion in groundwater. The plot of $\mathrm{Na} / \mathrm{Ca}$ versus $\mathrm{Mg} / \mathrm{Ca}$ molar ratio by Han and Liu (2004) was used to evaluate the groundwater and rock type association.

Features that are generally considered to determine suitable quality of groundwater for irrigation are salinity, water infiltration rate, and specific ion toxicity. Hence, ECw, major ions $\mathrm{Ca}^{2+}, \mathrm{Mg}^{2+}, \mathrm{Na}^{+}, \mathrm{K}^{+}, \mathrm{HCO}_{3}^{-}, \mathrm{SO}_{4}^{2-}, \mathrm{Cl}^{-}, \mathrm{SAR}$, TDS, $\mathrm{pH}$ were analyzed as the evaluation indexes of water quality for irrigation purpose. SAR, N\%, and IP are calculated by mathematical formula:

$$
\begin{gathered}
S A R=\frac{N a^{+} \mathrm{me} / 1}{\sqrt{\frac{\left(C a^{2+} \mathrm{me} / \mathrm{l}\right)+\left(M g^{2+} \mathrm{me} / \mathrm{l}\right)}{2}}} \\
\% N a=\frac{(\mathrm{Na}+\mathrm{K})}{\mathrm{Ca}+\mathrm{Mg}+\mathrm{Na}+\mathrm{K}} \times 100 \\
I P=\frac{\mathrm{Na}+\sqrt{\mathrm{HCO}-}}{\mathrm{C} a+\mathrm{Mg}+\mathrm{Na}} \times 100
\end{gathered}
$$




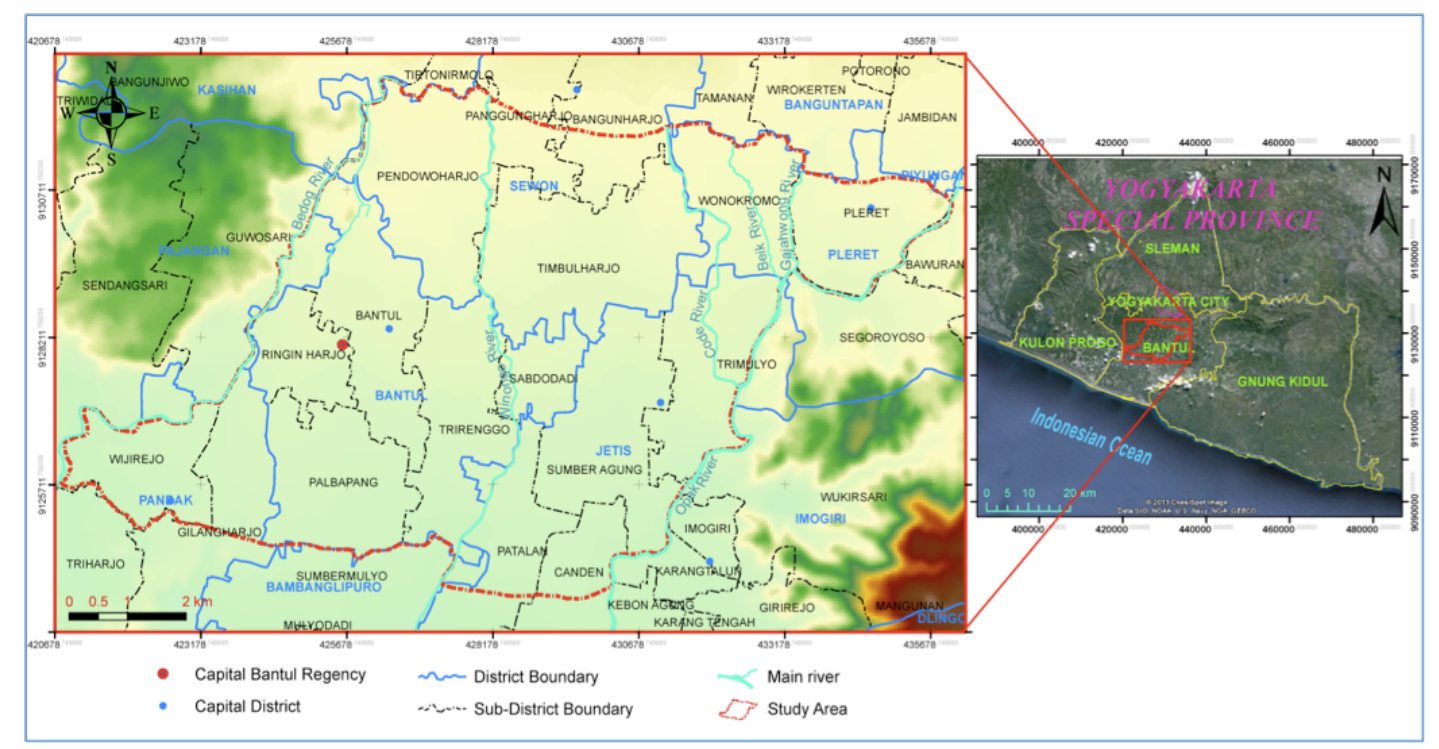

Figure 1: Location of study area.

Furthermore, classification method such as Richards (1954) was used to rate the water quality for irrigation purpose based on $\mathrm{ECW}$ and SAR. U.S. Salinity Laboratory diagram (USSL, 1954), Wilcox Diagram Interpretation (1948), and Doneen's Permeability Index (PI) were used to evaluate the groundwater quality for irrigation purpose.

Thematic Maps of suitable groundwater quality for agricultur was generated by covering the four main processes of GIS works. These working processes have been modeled in the Figure 2 .

1. GIS application is used to interpolate features of groundwater quality data with the output of surface raster. In this process, the numerical data of water quality will be imported into the ArcGIS program. Microsoft Excel was used to transport data to ArcView project. After making coordination system projection, the feature data point can be interpolated. Geostatistical interpolation by Kriging method was utilized by using ArcGIS software as well. The different spatial distribution of each parameter will be obtained in form of raster dataset.

2. The spatial distribution of groundwater quality feature will be determined by using Standard Analytical Guideline of Water Quality for Agriculture by FAO. The guideline is applied though the ModelBuilder which use Map Algebra expression. The expressions that are used in Map Algebra are condition $(C O N)$ and Boolean operators $(A N D, O R)$, Greater Than $(G T)$, Less Than $(L T)$ and Merge expression. The outputs were plotted in Thematic Maps (TM) which enable to determine the area of groundwater quality restrict on crops.

3. The selected crops yield in the study area was estimated base on ECW of groundwater and the tolerance rate of crops. Raster dataset of ECW spatial distribution in the study are was classified correspondently to the percentage of yield potential.

4. The final output thematic map was the overlay between thematic map of crops yield potential and land use. This would ended up with the thematic map of groundwater suitable for agriculture in which the area of different yield potential can be calculated by data querying in the attribute table.

\section{Results and discussion}

The analysis resulted from laboratory and secondary data showed the min, max, mean and SD value of 10 groundwater quality parameters in Table 2 . 


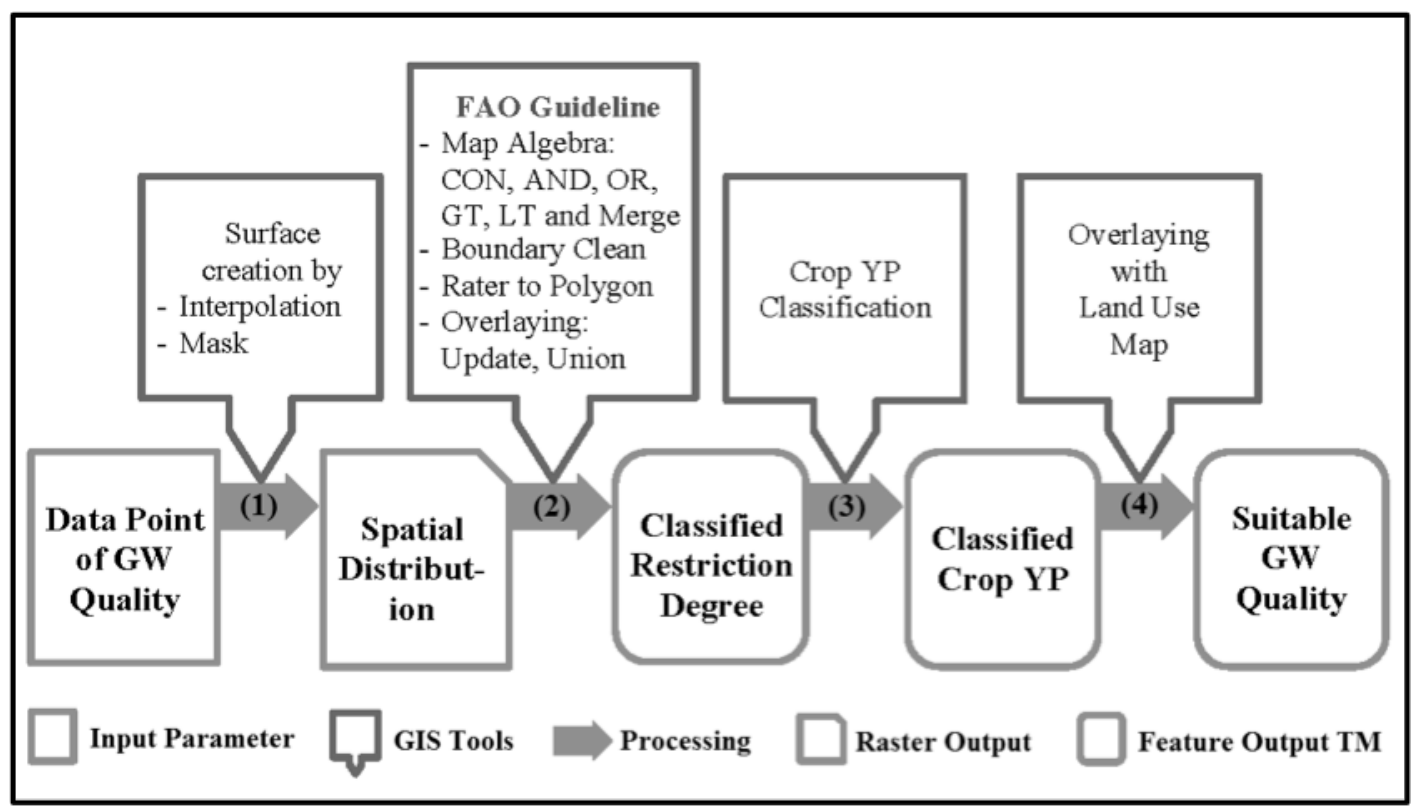

Figure 2: Conceptual model of GIS working process.

Table 2: Parameters of groundwater quality.

\begin{tabular}{|c|c|c|c|c|c|c|}
\hline Parameters & Unit & Min & Max & Mean & $\begin{array}{l}\text { Standard } \\
\text { Deviation }\end{array}$ & $\begin{array}{c}\text { Number of } \\
\text { Data }\end{array}$ \\
\hline \multicolumn{7}{|l|}{ Physics } \\
\hline $\mathrm{EC}_{\mathrm{W}}$ & [umhos/cm] & 287 & 1825 & 645 & 388 & 58 \\
\hline TDS & {$[\mathrm{mg} / \mathrm{l}]$} & 64 & 992 & 433.56 & 167.91 & 35 \\
\hline \multicolumn{7}{|l|}{ Chemicals } \\
\hline $\mathrm{pH}$ & -- & 6.4 & 7.87 & 7.29 & 0.349 & 78 \\
\hline $\mathrm{Na}$ & {$[m g / l]$} & 18.5 & 190 & 57.17 & 31.77 & 36 \\
\hline $\mathrm{K}$ & {$[m g / l]$} & 0.32 & 670.17 & 110.55 & 144.88 & 38 \\
\hline $\mathrm{HCO}_{3}{ }^{-}$ & {$[\mathrm{mg} / \mathrm{l}]$} & 35 & 436 & 210.97 & 63.15 & 38 \\
\hline $\mathrm{NO}_{3}^{-}$ & {$[\mathrm{mg} / \mathrm{l}]$} & 0.01 & 147 & 9.97 & 21.22 & 78 \\
\hline $\mathrm{Cl}^{-}$ & {$[\mathrm{mg} / \mathrm{l}]$} & 16 & 158 & 36.21 & 24.35 & 76 \\
\hline $\mathrm{SO}_{4}^{2-}$ & {$[\mathrm{mg} / \mathrm{l}]$} & 5 & 96 & 41.56 & 31.82 & 10 \\
\hline $\mathrm{Ca}$ & {$[\mathrm{mg} / \mathrm{l}]$} & 24 & 124.3 & 67.08 & 24.43 & 38 \\
\hline $\mathrm{Mg}$ & {$[\mathrm{mg} / \mathrm{l}]$} & 12.2 & 67 & 36.78 & 10.56 & 38 \\
\hline
\end{tabular}




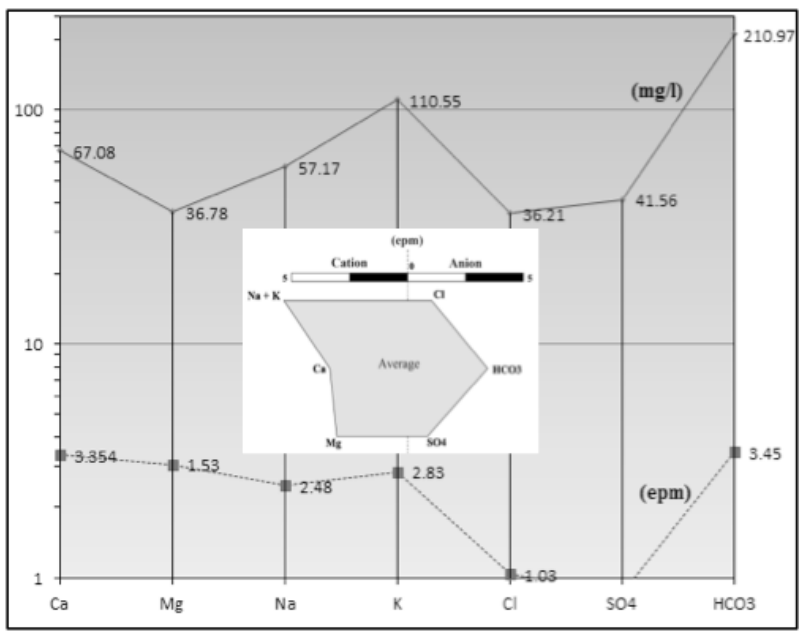

Figure 3: Schoeller diagram showing average composition in $\mathrm{mg} / \mathrm{l}$ and epm of groundwater in the study area. Stiff diagram is showing in inset

\subsection{Water and rock interaction}

Geochemistry of groundwater is discussed by means of it majors ions. Schoeller (1977) diagram provides a convenient way to present chemical composition of groundwater of a region. Plots of average composition, both in $\mathrm{mg} / \mathrm{l}$ and epm are presented in Figure 3. The relative tendency of ion in epm shows $\mathrm{Ca}^{2+}>\mathrm{K}^{+}>\mathrm{Na}^{+}>\mathrm{Mg}^{2+}$ and anion $\mathrm{HCO}_{3}^{-}>\mathrm{Cl}^{-}>\mathrm{SO}_{4}^{2-}$. According to Hem (1989), the estimate of average value of $\mathrm{Ca} / \mathrm{Mg}$ ratio is 1.82 , indicating complexity in the budget of $\mathrm{Ca}$ and $\mathrm{Mg}$ of groundwater due to the interaction with rock and soil material of the study area. Han and Liu (2004) have used the variations in the composition of water $(\mathrm{Mg} / \mathrm{Ca}$ versus $\mathrm{Na} / \mathrm{Ca}$ in molar ratio) to distinguish limestone, dolomite and silicate rock sources of ions. From the 36 samples, the study area is close to silicate rock with influence of carbonate rock in vicinity (Figure 4). The studied samples have $\mathrm{Na} / \mathrm{Cl}$ molar ratio 0.59 to 6.35 , suggesting that some $\mathrm{Na}$ is derived from Na-bearing rock or by exchange with Ca (Langmuir, 1997). Groundwater that has more $\mathrm{HCO}_{3}$ and less $\mathrm{Cl}$ ions ids an indication of natural water with no influx of pollution (Gholami and Srikantaswamy, 2009).

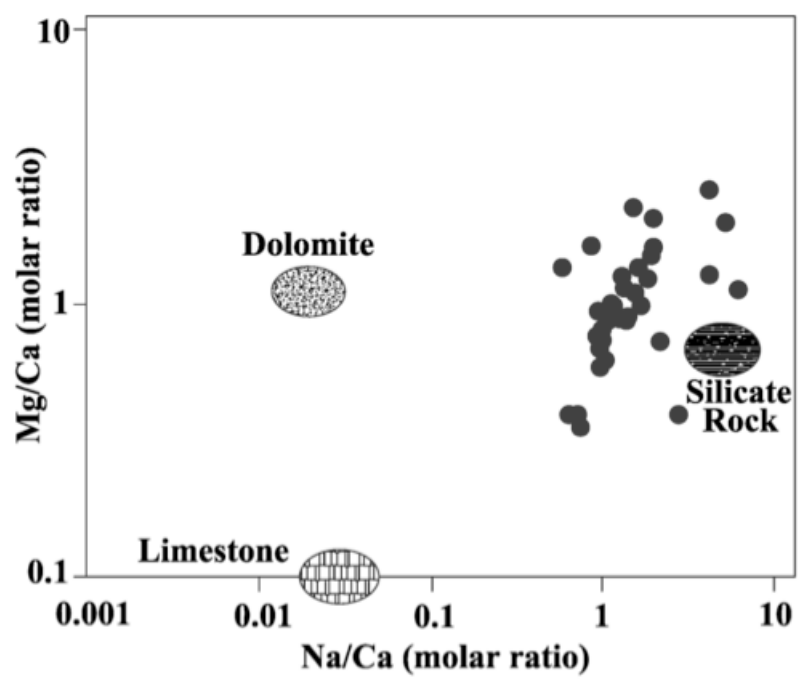

Figure 4: Plots of $\mathrm{Na} / \mathrm{CavsMg} / \mathrm{Ca}$ molar ration of groundwater in the study area (after Han and Liu, 2004).

\subsection{Irrigation water quality evaluation}

Based on Wilcox (1995) classification, $75.86 \%$ of samples (equal to $76.27 \%$ of the study area) falls into moderately saline water category, while the rest $24.13 \%$ of samples (equal to $23.64 \%$ of the study area) is classified into Medium to High saline water.

According to U.S. by Richards (1954), the majority of samples fall under the category of C2S1 and C2-S2 class, indicating good to medium groundwater type which is suitable for irrigation (Figure 5). According to the classification of Doneen (1964), all of the groundwater samples fall into class I (Figure 6). These results of PI suggests that groundwater is good and suitable for irrigation. Wilcox (1948) also classifies groundwater by \%Na value (Figure 7); all groundwater samples in the study area is in "excellent" class.

Hence, sodium hazard and permeability in the study area did not cause the problem on crops. However, it has some restriction due to the salinity problem that indicated via ECW.

\subsection{Determination of groundwater quality for agriculture by FAO Guideline}

According to FAO Guideline classification on restriction (criteria on Table 4 ), the salinity problem shows in ECw map indicates the presence 


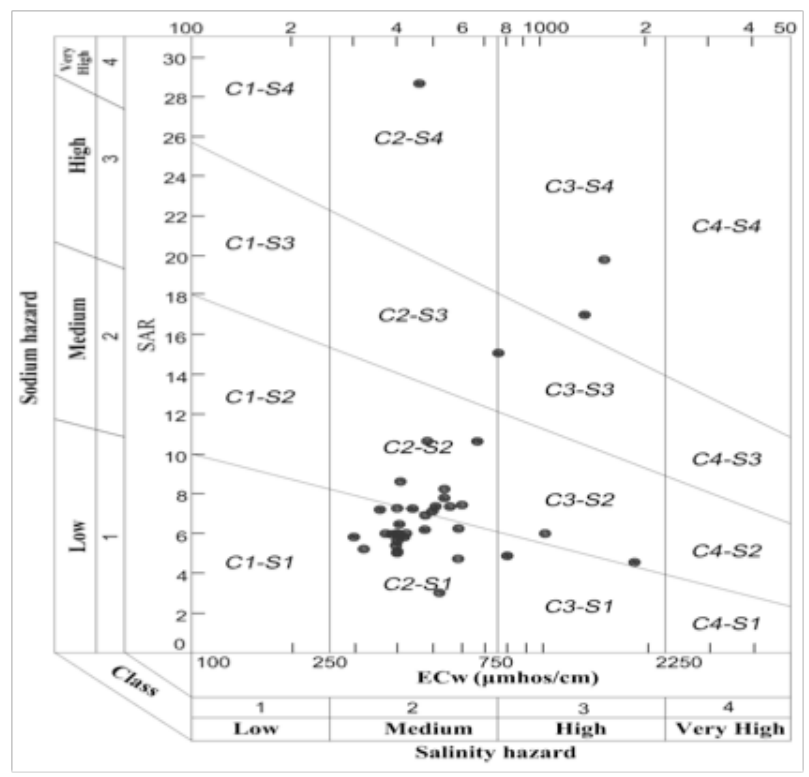

Figure 5: Classified based on U.S. Salinity Laboratory diagram.

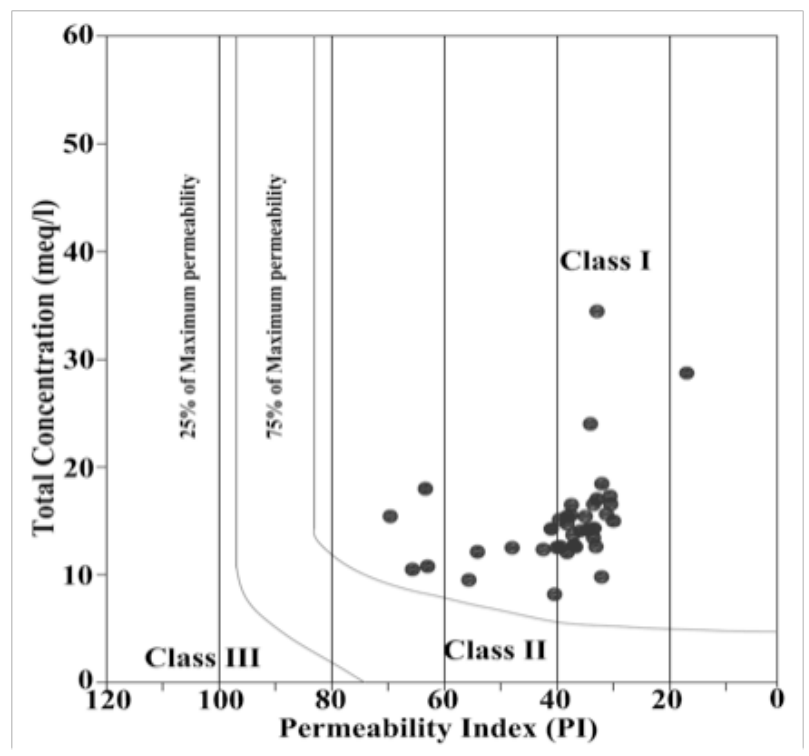

Figure 6: Classification of irrigation water by permeability (Richards, 1954) index based on Doneen (1964).

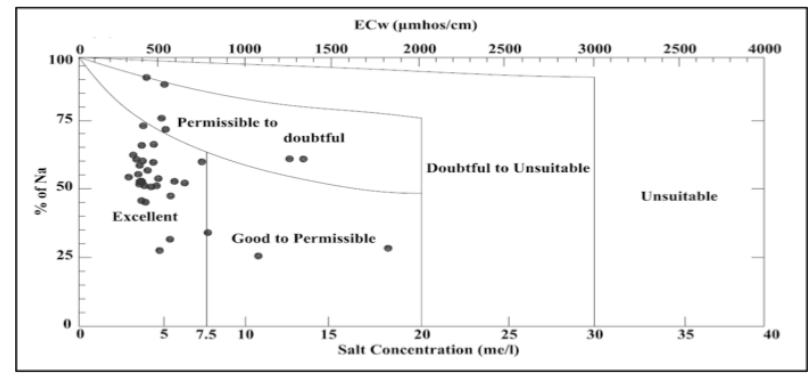

Figure 7: Irrigation water quality classification based on Wilcox's Diagram (1948).

of higher value that falls in the range between of 380 to over $1377 \mu \mathrm{mhos} / \mathrm{cm}$ in the west border of study area. The ECw map indicates the presence of about 5136.3 ha or approximately $72.65 \%$ of the whole study area is "None" restriction on the use for crop and the area 1933.85 ha about $27.35 \%$ has "Slight to moderate" restriction. The latter covers the north of Pandak district and the west part of Bantul and Sewon district along Bedog River. There is no "Severe" restriction on use for crop in the study area. The spatial distributions of the total dissolved solids (TDS) values was generated according to ECw map (Figure 8a). Permeability problem shows in Figure $8 \mathrm{p}$ was considered on SAR combined with ECw, resulted in "Slight to moderate" and "Severe" affecting $74.22 \%$ and $25.69 \%$ of the area, respectively.

The analytical map of groundwater quality for Specific Ion Toxicity (affecting sensitive crops) is shown in Figures 8 ; and based on $\mathrm{Na}+$ (SAR). The $71.07 \%$ of the area is in "slight to moderate" category and $28.93 \%$ is classified into "severe" restriction which is located at the west part of the study area near Pajagan district. This result is really close to $\mathrm{ECW}$ thematic map. $\mathrm{Cl}$ - concentration is from $16 \mathrm{mg} / 1$ to $158 \mathrm{mg} / \mathrm{l}$, which are mostly lower than criteria of restriction on use. Thus, it does not cause any problem for the crops in this area. The Miscellaneous Effects shows in Figure $8 \mathrm{~d}$ is indicated by Nitrogen.

The map resulted from crops yield potential as influenced by water salinity indicates a different tolerance rate of crop such as moderately tolerance, moderately sensitive and sensitive crops, as shown in Table 3 . 

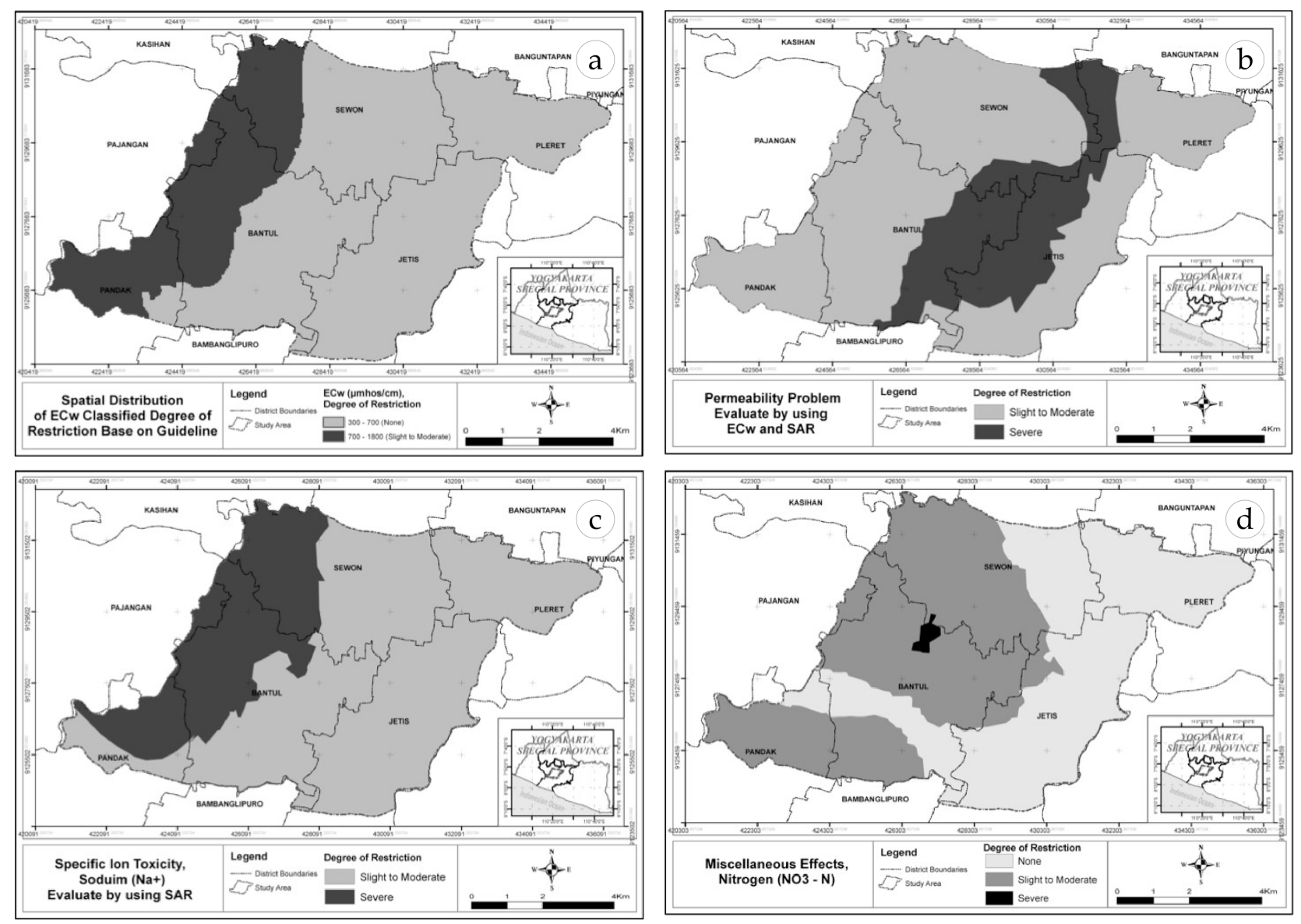

Figure 8: Spatial distribution of the TDS (a), permeability problem (b), groundwater quality for specific ion toxicity (c) and miscellaneous effects (d).

Table 3: Yield potential of crops as influenced by irrigation water salinity.

\begin{tabular}{|c|c|c|c|c|c|}
\hline Tolerance & Salinity (ECw) at & \multicolumn{2}{|c|}{ Percentage of Area in different Yield Potential } \\
\cline { 5 - 6 } salinity & Selected crops & $\begin{array}{c}\text { Shich yield loss } \\
\text { begins }\end{array}$ & $\mathrm{YP}=100 \%$ & $\mathrm{YP}=90 \%$ & $\mathrm{YP}=75 \%$ \\
\hline $\begin{array}{c}\text { Moderately } \\
\text { tolerant }\end{array}$ & Rice (paddy) & $>2000 \mu \mathrm{mhos} / \mathrm{cm}$ & $100 \%$ & -- & -- \\
\hline $\begin{array}{c}\text { Moderately } \\
\text { sensitive }\end{array}$ & $\begin{array}{c}\text { Sugarcane and } \\
\text { Corn }\end{array}$ & $>1100 \mu \mathrm{mhos} / \mathrm{cm}$ & $95.30 \%$ & $4.62 \%$ & -- \\
\hline Sensitive & $\begin{array}{c}\text { Bean and } \\
\text { most of } \\
\text { vegetative } \\
\text { crops }\end{array}$ & $>700 \mu \mathrm{mhos} / \mathrm{cm}$ & $72.58 \%$ & $20.10 \%$ & $7.17 \%$ \\
\hline
\end{tabular}


Table 4: Criteria for the classification of thematic maps of groundwater quality for irrigation and their spatial distribution (FAO, 1985).

\begin{tabular}{|c|c|c|c|}
\hline \multicolumn{4}{|c|}{ Criteria Degree of restriction on useArea (\%)Area $\left(\mathrm{Km}^{2}\right)$} \\
\hline \multicolumn{4}{|c|}{ Salinity (affects crop water availability) } \\
\hline \multicolumn{4}{|c|}{ ECw $(\mu \mathrm{mhos} / \mathrm{cm})$} \\
\hline None & $<700$ & 72.65 & 51.3631 \\
\hline Slight to moderate & $700-3000$ & 27.35 & 19.3385 \\
\hline Severe & $>3000$ & --- & --- \\
\hline \multicolumn{4}{|l|}{ TDS (mg/l) } \\
\hline None & $<450$ & 69.63 & 49.2319 \\
\hline Slight to moderate & $450-2000$ & 30.37 & 21.4645 \\
\hline Severe & $>2000$ & --- & --- \\
\hline \multicolumn{4}{|c|}{ Permeability (affects infiltration rate of water into the soil) } \\
\hline SAR $=0-3$ & ECw (mmhos/cm) & & \\
\hline None & $>700$ & 0.00 & 0.00 \\
\hline Slight to moderate & $700-200$ & 0.00 & 0.00 \\
\hline Severe & $<200$ & 0.00 & 0.00 \\
\hline$S A R=3-6$ & ECw (mmhos/cm) & & \\
\hline None & $>1200$ & 0.00 & 0.00 \\
\hline Slight to moderate & $1200-300$ & 23.16 & 16.3861 \\
\hline Severe & $<300$ & 0.00 & 0.00 \\
\hline SAR $=6-12$ & ECw (mmhos/cm) & & \\
\hline None & $>1900$ & 0.00 & 0.00 \\
\hline Slight to moderate & $1900-500$ & 51.06 & 36.1243 \\
\hline Severe & $<500$ & 25.71 & 18.19 \\
\hline SAR $=12-20$ & ECw (mmhos/cm) & & \\
\hline None & $>2900$ & 0.00 & 0.00 \\
\hline Slight to moderate & $2900-1300$ & 0.00 & 0.00 \\
\hline Severe & $<1300$ & 0.00 & 0.00 \\
\hline \multicolumn{3}{|c|}{ Specific Ion Toxicity (affects sensitive crops, Surface Irrigation) } & \\
\hline None & $<3$ & 0.00 & 0.00 \\
\hline Slight to moderate & $3-9$ & 71.07 & 50.2822 \\
\hline Severe & $>9$ & 28.93 & 20.4550 \\
\hline \multicolumn{4}{|l|}{$\mathrm{Cl}^{-}(\mathrm{mg} / \mathrm{l})$} \\
\hline None & $<140$ & 100 & 70.743 \\
\hline Slight to moderate & $140-350$ & 0.00 & 0.00 \\
\hline Severe & $>350$ & 0.00 & 0.00 \\
\hline \multicolumn{4}{|c|}{ Miscellaneous Effects (affects susceptible crops) } \\
\hline \multicolumn{4}{|c|}{ Nitrogen $\left(\mathrm{NO}_{3}-\mathrm{N}\right)(\mathrm{mg} / \mathrm{l})$} \\
\hline None & $<5$ & 47.80 & 33.80 \\
\hline Slight to moderate & $5-30$ & 51.46 & 36.40 \\
\hline Severe & $>30$ & 0.59 & 0.4229 \\
\hline
\end{tabular}


Specifically, observation of land use map with yield potential of sensitive crops overlay shows that the crops land with $100 \%$ Yield Potential is about 2727.90 ha, equals to $38.56 \%$ of the whole area. This crops land is corresponded to "None" restriction of the Guideline. Whereas the crops land in which the Yield Potential can reach $90 \%$ is counted as "Slight" restriction with approximately 735.49 ha or $10.39 \%$ of the study area. The last is crops land which is considered as "Moderate" restriction. the Yield Potential is only $75 \%$ or about 208.98 ha, equals to $2.95 \%$ of the area (Figure 9). The result of suitability of groundwater quality for agriculture is summarized in the Table 5 .

\section{Conclusion}

An analysis of groundwater quality is essential for a proper understanding of the present environmental problems and geological condition controlling. The present study demonstrated high efficiency of GIS utilization to analyze complex spatial data. A different component and data should be incorporated into GIS applications to determine its physical suitability. With an adequate database, Geographic Information Systems (GIS) can serve as a powerful analytical and decision making tool for agriculture development. The groundwater quality thematic map which was prepared based on the spatial data analysis shows that the GIS assisted database system would help to apply groundwater management practices, such as proper groundwater resource management in terms of groundwater quality and quantity, and integrated management of water, land use, and the environment. The produced groundwaterrelated database can help as information source to institutions, researchers, or other relevant sectors.

Furthermore, the result of study can be concluded as following:

- The result of this study indicates that important parameters of groundwater such as IP, SAR the $\mathrm{pH}$, and other major ions are within the specified limit suitable for irrigation purpose, except ECw and sodium which are at the margin and mainly affect the groundwater quality and crops yield in the study area.

- However, the general evaluation with all discussed parameters shows that groundwater quality in the study area is in good rank for irrigation purpose. Yet, ECw shows slight to moderate restriction on crops productivities. The severity is getting higher to the west of the Bantul in sub-district of Guwusari, Bantul, Pendowoharjo, Ringinharjo, Gilangharijo and Wijirijo where the groundwater quality are driven by the contribution of dissolution of carbonate parent rock and expose limestone of Sentolo hill and the natural groundwater in the study area does not have influx of pollution.

- The thematic map reveals that good groundwater quality for crops' irrigation water is especially at the middle and the east of the study area close to Opak River. The groundwater quality in the West affects in situ irrigation water but there is no effect on yield potential for tolerant crops such as rice, but has slightly to moderately restriction on sensitive crops such as common bean and other vegetative crops as shown in the thematic map of agricultural land in different yield potential (Figure $09)$. The crop land in which yield potential $100 \%, 90 \%$ and $75 \%$ is about 2727.90 ha $(38.56 \%), 735.49$ ha $(10.39 \%)$ and 208.98 ha $(2.95 \%)$ of the study area respectively.

\section{References}

Ayers, R. and Westcot, D. (1976). Water quality for agriculture. Rome, Italy : FAO.

Bernstein, L. (1975). Effects of salinity and sodicity on plant growth. Ann. Rev.: Phytopathol.

Doneen L. D. (1964). Notes on water quality in agriculture. Published as a Water Science and Engineering Paper 4001, Department of Water Science and Engineering, University of California.

ESRI. (2007). Introduction Working with ArcGIS Spatial Analyst. New York: ESRI.

Ganapathy, C. and Ernest, A. (2004). Water 
Table 5: Result summary of suitability of groundwater quality for agriculture in the study area.

\begin{tabular}{|c|c|l|c|c|c|}
\hline \multirow{2}{*}{$\begin{array}{c}\text { Des- } \\
\text { cript- } \\
\text { ion }\end{array}$} & \multicolumn{2}{|c|}{ Study Area } & \multicolumn{2}{c|}{ Degree of Restriction on Crops and Relative Yield } \\
Potential (\%)
\end{tabular}




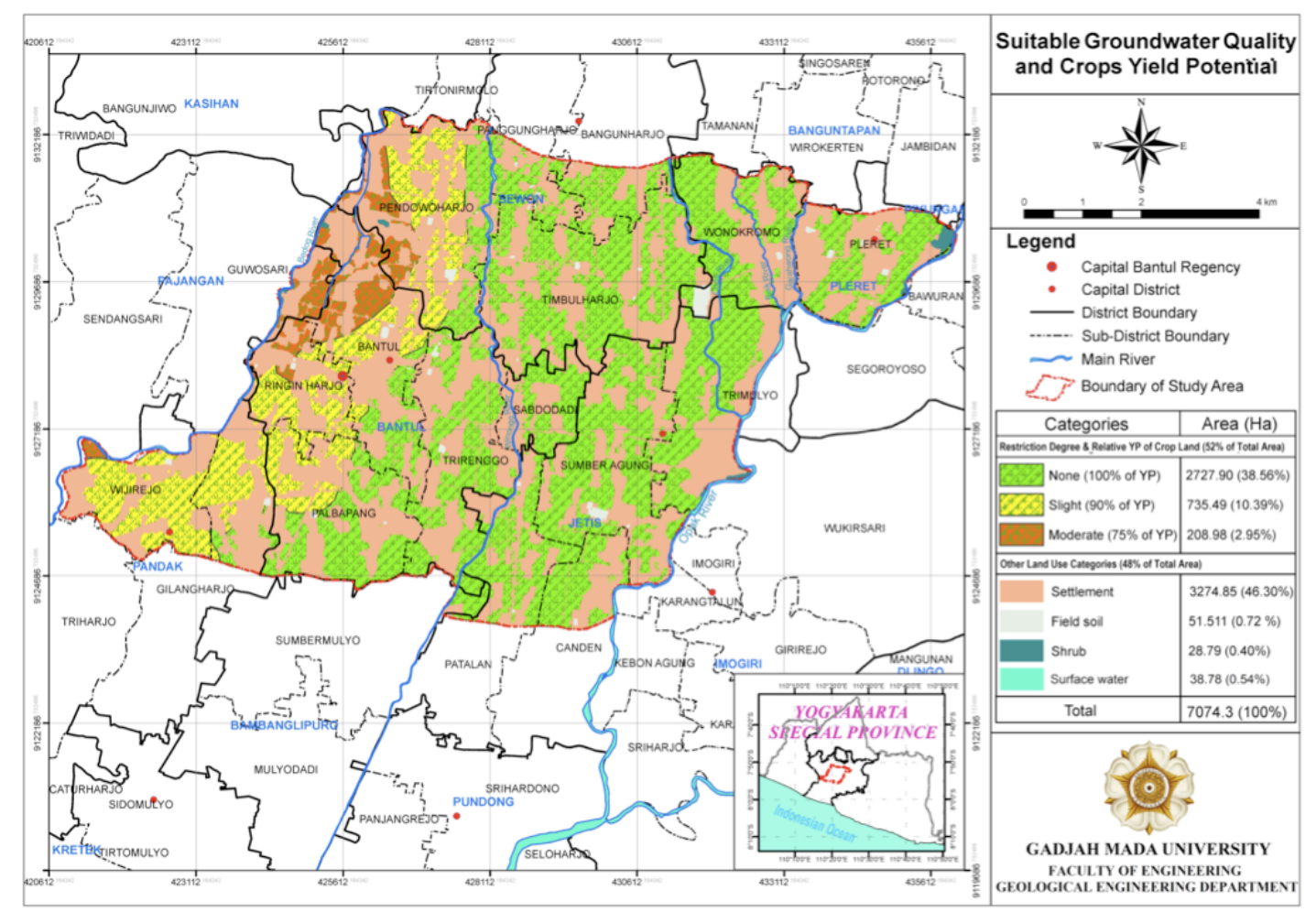

Figure 9: Suitability of groundwater quality for agriculture and relative crops yield potential.

Quality Assessment Using Web Based GIS and Distributed Database Management Systems. Arch.: Environ. Inform.

Gholami, S. and Srikantaswamy, S. (2009). Analysis of Agriculture Impact on the Cauvery River water around KRS Dam. World Applied Sciences Journal, 6 (8), 1157-1169.

Han, G. and Liu, C. Q. (2004). Water geochememistry controlled by carbonate dissolution : a study of the river waters draining karst dominated terrain, Guizhou Province, China. China Chemical Geology, 204, 1-21.

Hem, J. M. (1989). Study and interpretation of the chemical characteristics of natural water (3rd ed.), Water Supply Paper 2254. Washinton DC: USGS .

Langmuir, D. (1997). Aqueous environmental geochemistry, McConnin RA (ed). Englewood Cliffs, NJ.: Prentice-Hall.

M. Mac Donald and Partners, Binniea nd Part- ners Hunting Technical Service Ltd. (1984). Greater yogyakarta Groundwafer Resources Study volume 2, Hydrology, Directorate General of Water Resources, Groundwar Development Project ( P2AT. Ministry of Public Works, Govemment of the Republic of lndonesia.

Richards, L. A. (1954). Diagnosis and improvement of saline and alkali soils. USDA Agricultural Handbook No. 60. Washington DC: US Department of Agriculture.

Schoeller, H. (1977). Geochemistry of groundwater, In Groundwater Studies - An International Guide for Research and Practice. Paris: UNESCO.

Wilcox, L. V. (1948). The quality of water for irrigation use. Tech Bulletin 962, 40.

Wilcox, L. V. (1955). Classification and Use of Irrigation Waters. Washington D C: USD Circular No. 969. 